\title{
Una conversación sobre la investigación audiovisual de estallidos sociopolíticos en clave juvenil
}

\section{Sammy Riley}

\section{Presentación}

Después de pasar 13 años felizmente viviendo en Colombia, algo que siempre me ha fascinado de este país es su lucha, en todas sus manifestaciones. Actualmente estoy haciendo una investigación que tiene un documental como producto final, así que de ahí surge mi interés en el tratamiento audiovisual de la lucha colombiana y mi deseo de conversar sobre esta forma de comprender las realidades.

Pensé en el Laboratorio Creativo de Antropología Audiovisual, ${ }^{2}$ del cual fui estudiante el año pasado. Uno de los líderes del Laboratorio, Carlos Cárdenas Ángel, ${ }^{3}$ fue realizador de Fusiles de madera ${ }^{4}$ (2002), una investigación audiovisual del estallido sociopolítico que era la guerrilla en Colombia a finales del siglo XX y retrata un campamento de entrenamiento del Ejército de Liberación Nacional (ELN). Este documental fue parte de la tesis de pregrado de Carlos, un joven investigando este estallido sociopolítico con una cámara en la mano, preguntando por qué otros jóvenes decidieron emprender un proyecto de vida tan extremo como era unirse a la

\footnotetext{
${ }^{1}$ Comunicador Social de la University of South Australia. Magíster en Desarrollo Comunitario y Educativo de la Universidad Pedagógica Nacional. Candidato a Doctor en Ciencias Sociales, Niñez y Juventud del Cinde y la Universidad de Manizales.

${ }^{2}$ Febrero-mayo, 2019 en Bogotá; organizado por la Asociación Colombiana de Antropología.

3 Antropólogo de la Universidad Nacional de Colombia. Magíster en Antropología Social de la Universidad Federal de Santa Catarina, Brasil.
}

${ }^{4}$ https://vimeo.com/23023429 
guerrilla en ese momento. Reconocida como una de las tesis audiovisuales más vistas del continente, Fusiles de madera vibra por su producción, experimentación y por el conocimiento que produce sobre los jóvenes reclutados por la guerrilla.

También pensé en mi compañera del Laboratorio, Camila Camacho, 5 artista, antropóloga e integrante de la colectiva feminista La partida, quien realiza trabajos audiovisuales como el video del performance Un violador en tu camino ${ }^{6}(2019)$ durante el estallido sociopolítico que irrumpió en Colombia el año pasado. Egresada de Artes Plásticas y Antropología, Camila produce videos, fotografías y documentales con otros jóvenes para comprender las realidades juveniles actuales. La colectiva feminista La partida toma acción tanto en el mundo virtual como en el mundo físico y fue activa y presente durante las protestas de $\mathrm{N}_{21}$ y N25 el año anterior.

Decidí reunir a estos dos investigadores con experiencia en utilizar lentes y micrófonos para investigar jóvenes que protagonizan los estallidos sociopolíticos de dos momentos específicos en la historia del país. Refiriendo a los trabajos de Carlos y Camila, nuestra conversación recorre la formulación y preparación de la investigación audiovisual de un estallido sociopolítico, el momento de realizarlo, el conocimiento y sentidos que producen estas obras. Finalmente, hablamos del futuro de la investigación audiovisual en un mundo cohibido por la pandemia.

Le recomiendo al lector, si tiene tiempo, ver los trabajos audiovisuales de Camila y Carlos citados arriba antes de leer esta entrevista. ${ }^{7}$

Sammy Riley (S. R.): Carlos, primero quiero preguntarte, ¿por qué tomaste una cámara, te metiste en un campamento de guerrilleros y arriesgaste tu vida para hacer tu tesis audiovisual de pregrado?

Carlos Cárdenas Ángel (C. C. Á.): Cuando entré a estudiar antropología, sin tener todavía claro todo el tema de la antropología visual, ni que existía, empecé a tener claro que era por ahí que me iba a llevar a caminar este camino disciplinar.

Muy rápido empecé a angustiarme — creo que esto lo hablamos en el Laboratorio—; muy rápido me empecé a dar cuenta de cómo la dinámica de la academia en antropología y en la Nacional ${ }^{8}$ específicamente era absorber mucha información y muchos libros para uno digerirlos y construirse teórico-conceptualmente en todos estos andamiajes, para después uno producir ese

\footnotetext{
5 Antropóloga y artista plástica de la Universidad Pontifica Javeriana.

6 https://youtu.be/YRCjk8u6faQ

7 Esta entrevista ha sido editada por razones de espacio.

8 Universidad Nacional de Colombia, sede Bogotá.
} 
mismo tipo de andamiajes o seguir reproduciendo extensiones a veces bastante estériles. Entonces era la angustia que eso era un conocimiento que no iba a salir realmente hacia afuera de la academia y muy rápidamente me di cuenta de que una posibilidad era este otro tipo de lenguajes - lo audiovisual - era una posibilidad para producir conocimiento antropológico. No solo que tuviera otras posibilidades, otras potencialidades expresivas y comunicativas, sino otro alcance, otro nivel de accesibilidad por fuera de la academia.

En ese momento el golpe de suerte fue que había un proyecto grandísimo (del Departamento de Antropología) de arqueología de rescate en el Magdalena Medio. Estaban en un proyecto enorme de ir a hacer estudios de impacto social de los oleoductos, gasoductos y yacimientos que iban a explorar allá. Entonces estaba yendo mucha gente a eso; estudiantes que iban a hacer sus prácticas allá.

Y por eso se generó un relacionamiento de los estudiantes con los actores en la región, entre esos el ELN y organizaciones de base. Eso permitió que ellos hicieran una fuerte conexión con esas organizaciones y esos sectores cercanos al ELN. Yo me fui por un lado más radical que no fue con las comunidades, sino directamente con estos locos, y fue en conjunto con un compañero, Carlos Duarte, quien estaba más en la onda de trabajar la antropología simbólica. Él también era del colectivo Kino Pravda $\mathrm{y}$ decidimos hacer «llave» porque era un tema más retador y queríamos aprovechar el riesgo que íbamos a asumir para recoger algo un poco más robusto.

Entonces se dio la posibilidad, con esta gente que había generado confianza con estos sectores de allá, para poder empezar las discusiones, las charlas. Después nos tocó ir y, pues sí, meternos tal cual selva adentro para tener una reunión, un viaje como de dos semanas para tener una reunión como de hora y media con la élite, los comandos de la zona. Un pitch, ${ }^{10}$ básicamente; fue un pitch para la tesis y nos fue bien. Solo un par de personas hicieron cara que nos querían tragar, pues muy prevenidos obviamente con el tema de que llegara algo así, muy raro, y sobre todo gente ya mayor, como muy anquilosada en las costumbres y las creencias de ese mundo guerrillero. Pero tuvimos también la suerte de que dimos con gente muy abierta y que entendía que lo que nosotros íbamos a hacer también les podía ayudar a ellos a abrir una reflexión interna, pero también una nueva forma de que los vieran hacia afuera.

¿Cómo decidimos manejar el tema de la antropología visual en esa tesis? Al principio nunca quisimos hacer un documental; eso fue algo que resultó después de tener una tesis escrita y de sentir que había algo que hacer. Inicialmente lo que queríamos era que el video y las

9 http://antropologosuncolombia.blogspot.com/2007/10/kino-pravdagrupo-de-antropologa-audio.html

1o Una presentación verbal concisa de una idea para una película. 
imágenes fueran una caja de herramientas en varios sentidos. Hacer un diario de campo audiovisual; grabar en cámara casi todo lo que pudiéramos, cotidianidades, todo lo que nos permitieran grabar y nosotros mismos, que también entramos en el juego, el tema de la reflexividad.

Otra posibilidad, como herramienta para las discusiones y reflexiones, era llevar audiovisuales para verlos con ellos y confrontarlos; algunos documentales ya hechos que contaban historias del conflicto armado, cosas así. Pero otros, por ejemplo, donde nosotros aquí nos tomamos el trabajo de salir a la calle y grabar a la gente preguntándole: ¿usted cómo se imagina un guerrillero del ELN?, ¿cómo describiría un guerrillero? Indagar un poco ese imaginario para llevar esas opiniones y confrontárselas a ellos; eso fue fuerte.

Y, por último, como recurso, tratamos de recoger de una idea de unos locos que en los años setenta habían trabajado con los indígenas navajo en Estados Unidos; una idea que ellos llamaron de documentales. Ahí se juntaron un antropólogo y un cineasta para trabajar con los navajos con la hipótesis de que la visualidad también tiene sus particularidades culturales; que todos vemos de acuerdo con base en nuestra construcción cultural y a esos patrones que llevamos. El experimento fue enseñarles a estas comunidades navajo (a un grupito) a manejar la cámara, solo lo técnico básico: el carrete se mete así (eran súper 8 creo), aquí se cierra, aquí se abre. Es decir, lo básico (nada de planos, nada de nada), y ustedes cuenten la historia que quieran. Un poco con la idea de comprobar que ellos iban a encontrar unas narrativas muy diferentes a las occidentales.

Recogimos mucho material de estas diferentes posibilidades, de nuestro diario de campo, de las discusiones que se dieron con los videos que llevamos y los documentales que ellos hicieron. Inicialmente eso fue material para escribir un ladrillo enorme. Y, como te decía, al final fue ya después cuando teníamos la tesis, fue que dijimos: «Oiga, de aquí podemos sacar un documental chévere». Ya es más claro pensarlo como la estructura, a partir también de lo que quedó en la tesis, y ahí es que ya entonces finalmente sale Fusiles de madera. Fue un proceso de tres años, de una versión que duraba dos horas hasta ir empaquetándola a la versión final que dura una hora y que es la que ha circulado por ahí.

S. R.: Camila, cuando estuvimos conversando antes me comentaste que durante el paro nacional de Colombia del año pasado (2019), encontraste otras formas de pensar tu quehacer político, como joven, como mujer, como artista, como activista. ¿Puedes compartir con nosotros un poco este cambio que experimentaste participando en el paro? 
Camila Camacho (C. C.): El paro de noviembre ${ }^{11}$ fue fuerte para todos. Siempre iba a salir con comisiones de mujeres. Reconocí que era una primera forma de sentirme más segura siempre, y desde el 21, desde el primer día siempre estuve marchando con mujeres. Antes me daba miedo muchas cosas y después ya no; como que uno se siente más tranquila. Antes también llevaba la cámara a todas las marchas y después fue como no, estas fotos no sirven para nada. Pero digamos que ahorita tomamos fotos entre todas y también fue distinto.

Y pues ahí fue que salió eso, como esto de Las tesis ${ }^{12}$ que pasó en Chile y lo empezaron a convocar, pues porque aparte era el ${ }_{25} \mathrm{~N}^{13}$ que desde dos meses antes se había estado planeando. Es que esa marcha del 25 fue muy poderosa, pero al mismo tiempo fue muy extraña porque se fusionaron ambas marchas: la del paro y la de la violencia contra las mujeres; así que era una marcha de violencia contra las mujeres al lado del Partido Liberal, que estaba marchando por el parejo ${ }^{14}$, no lo sé, o en el mismo Congreso de los Pueblos, que tanto ha denunciado a hombres violentos. Éramos como parchecitos ${ }^{15}$ de a cinco, seis, al principio, y después como buscándonos entre todas y después veíamos que éramos 10, después como 20 y al final ya nos íbamos juntando entre nosotras porque no encontrábamos la marcha de mujeres en la marcha de mujeres; eso era muy extraño.

Después se convocó al primer performance de Las tesis. Igual era raro porque no nos conocíamos, pero nos hemos visto en todos estos lugares durante una semana y ya todos estábamos agotados. Igual fue muy agotador física y emocionalmente, y sentir los helicópteros, no sé, era como un estado muy extraño en ese momento.

Iba a hacer el performance, pero yo sentía que no quería hacer el performance; como que para mí era muy raro; me sentía muy incómoda, pero sabía que si llevaba mi cámara no me iba a sentir tan incómoda.

Mientras estuve ahí y las demás chicas sí participaron; otra compañera también tenía el mismo miedo de ser grabada, pero se siente cómoda grabando porque el performance realmente era para grabarlo, más allá de intervenir en un espacio físico. Les parece súper chévere el

\footnotetext{
${ }^{11}$ El paro nacional de Colombia empezó el 21 de noviembre o N21.

${ }_{12}$ Performance organizado por Las tesis en Chile: https://youtu.be/aB7r6hdoz $W_{4}$

13 Día Internacional de la Eliminación de la Violencia contra la Mujer.

14 Término coloquial que significa «al lado de nosotros».

15 Término coloquial que significa «grupos pequeños de personas».
} 
performance; pero era más, creo que era más un performance virtual. Y había mil, mil cámaras por todos lados.

Empezamos a grabar todos los ensayos. Una compañera se paraba desde el frente y yo desde más cerca. Después decidí que no lo iba a contar como alguien externo y por eso también decidí meterme entre las chicas. Creo que cambia mucho la mirada desde quien está afuera y quien está adentro, y eso también implica un punto de vista y una posición política.

Creo que eso sí me cambió. Después, a partir de eso sentí que el paro, no era solo por todas estas crisis que había, sino por pensar nuevas prácticas políticas que implicaban unas formas de cuidado al marchar, unas formas de cuidado en crear estas imágenes de otros y otras, unas formas políticas que atravesaban primero mi cuerpo y mis formas de relacionarme con estos otros y otras, y desde ahí cambió todo un poco.

Y aquí es importante también aclarar que si hubiera sido solo como Camila Camacho, no creo que me hubiera atrevido a hacer todo, como cuando estaba enmarcada como La partida, ${ }^{16}$ cuando se funde como mi propia individualidad, se piensa como un ejercicio colectivo donde igual estamos con otras chicas y así me siento más tranquila creando estas imágenes siempre. Que no sea un ejercicio mío, individual, del artista que le gusta retratar otras mujeres en la marcha, sino pensarlo también como un ejercicio colectivo y político de memoria o de registro de esto que se sale de mí misma también, pero que me atraviesa principalmente.

S. R.: Hablando de ese video, les cuento que la primera vez que lo vi, lloré; lloré al final y me sorprendí de llorar tanto porque sentí que captaba mucho de lo que vi y lo que viví en el paro, como ese sentido de esperanza para mí, como ver las caras, ver la emoción era muy importante. Quiero preguntarles a ustedes dos, ¿qué conocimiento, cuáles sentidos produce este video sobre el paro?

C. C.: Para mí era reconocer que el paro y la acción política tenían que pasar primero por mi cuerpo, mis afectos y que desde ahí se genera como la colectividad que hace más potente esta acción política colectiva. Estos encuentros con mujeres solo me han invitado a reconocer realmente desde dónde parte eso y de ser más reflexiva con eso. Es desde ahí y de generar esa colectividad lo que me hizo sentirme muy acompañada todo el tiempo, así no las conociera. Dejamos de pensarnos como una violencia individual o como un cuerpo agredido individualmente, sino que es un cuerpo colectivo que se tiene que juntar también para seguir desde ahí dándole, y creo que eso también me ayuda a sentirme acompañada y a tener una razón más clara para hacerlo.

16 Instagram: @lapartida.feminista 
C. C. Á.: Al ver el video una de las cosas que sí me tocó fuerte, pues es lo que decía un poco también Camila, que si bien es algo sutil, hay algo ahí en el manejo de cámara y en la forma como se aborda realizar ese trabajo, que uno se siente estando allá adentro. Uno no siente una masa llevando a cabo una acción, sino uno percibe o le gusta percibir de alguna forma las subjetividades que hay ahí: los individuos y sus posibles historias de vida.

El video es algo que me lleva a sentir eso; es ver rostros, es ver cómo a veces lo que uno siente de alguna forma es lo que expresa Camila: a veces como el temor, como la timidez a esta situación de expresarse así; pero también la fuerza, también la alegría con el desahogo, la alegría con el «nosotras», con esa cosa tribal. Me encanta el final con la chica que hace el sonido, muy clichesudo, ${ }^{17}$ indígena, pero porque sí creo que hay algo ahí muy tribal que es también lo que lo hace poderoso. Es también algo relacionado a lo que decía Camila hace un momento, de cómo ella se siente cómoda en este tipo de trabajos cuando hay un «nosotros» o un «nosotras» en el que uno se recoge para sentirse más fuerte, para sentirse más seguro, para sentirse que está donde debe estar y que puede hacer lo que quiere y debe hacer.

S. R.: Mi última pregunta es ahora que estamos en tiempos de Covid, tiempos pandémicos y la acción colectiva de las calles se ha desplazado a las redes, ¿cómo se puede hacer investigación audiovisual de la acción colectiva en cuarentena o desde la casa?

C. C. Á: Me quedó grabada una forma de decirlo que en estos días me comentó una persona de una organización de Brasil; ellos trabajan en la Amazonía brasileña y estábamos justamente hablando de cómo ellos están haciendo para llevar a cabo el trabajo que hacen allá. Ellos tienen un trabajo multifacético en esa región: trabajan con indígenas, agrupadas en quilombolas, ${ }^{18}$ que sería como consejos comunitarios, pero más territoriales en toda la zona amazónica. Y él lo que me decía es simplemente que lo que estamos haciendo no reemplaza lo que estaríamos haciendo si no estuviéramos con este tema de la pandemia, pero lo que estamos haciendo es simplemente para no quedarnos quietos.

Todo eso se ha congelado, se ha fragmentado, aminorado; empiezan otras prioridades porque ahora el tema humanitario cada vez empieza a inflarse más, más y más porque la gente está necesitando comida, está necesitando protección.

Creo que lo que se está haciendo es como lo mínimo para no quedarnos quietos, para mantener activas las redes, para mantener activos los vínculos; un cierto nivel de flujo de información y de cosas pasando, pero solo eso. Ya hay niveles de movilización social y de investigación social

${ }_{17}$ Término coloquial que significa «con textura de cliche».

18 Asentamientos habitados por personas afrodescendientes en Brasil. 
que es imposible; uno necesita sentir a la gente, uno necesita eso que transmite el video de La partida; de sentir que uno está en el mismo lugar con otros y otras, diciendo las mismas frases, haciendo los mismos movimientos hacia alguien o algo. Es ese tipo de sensaciones que estas cosas no las van a reemplazar del todo.

C. C.: Al principio de la cuarentena éramos así, como esto está muy denso o simplemente acompañándonos, y a partir de eso fue que quisimos hacer Las partidas de cuarentena ${ }^{19}$ como una forma de compartir esos sentires desde lo audiovisual.

Hicimos como un primer piloto antes de sacarlo por redes como para abrirlo a otras, que era ritmo lento, ${ }^{20}$ de cómo sentimos la cuarentena. Cada una desde sus espacios separados creaba una imagen, un video de zo segundos máximo sobre ritmo lento y lo subíamos a una carpeta y después todas nos sentábamos. Mientras los veíamos compartíamos un poco cómo esa persona sintió el ritmo lento; nos ayudaba mucho a sentirnos muy acompañadas en la cuarentena. Más allá de investigar sobre lo audiovisual, creo que fue una forma de compartir y sentir con el audiovisual como una excusa para hacerlo.

Después de Las partidas de cuarentena nos aburrimos de eso, porque sentíamos que igual no era como un trabajo colectivo en sí, porque era como cada una grabando y después contábamos nuestras individualidades. Queríamos generar un espacio de reflexión, y a partir de esa reflexión concertar qué imágenes grabar sobre estas reflexiones, y que las imágenes sean fruto de una reflexión colectiva, de decidir colectivamente qué imágenes grabar, que es un proceso distinto.

Empezamos a hacer una cosa que se llama Partidas contra el distanciamiento. La primera temática fue cuerpo e imagen; entonces hemos tenido como tres, cuatro sesiones alrededor de cuerpo e imagen para reflexionar también sobre ellos. Y esta semana, por ejemplo, que estamos haciendo un diario de autorretratos, porque también reconocemos que autorretratarnos es muy difícil y hacerlo público también, como una reflexión sobre cómo mostrar nuestro cuerpo, cómo hacer imágenes de nuestro cuerpo y así.

Creo que no ha cambiado, no queremos crear unas investigaciones. Es como la excusa y el medio para llegar a otras cosas que van más allá de la creación de imágenes en sí mismas porque también nos aporta más reflexiones, pero no es el centro.

\footnotetext{
19 https:/www.youtube.com/playlist?list=PLvlt8bh2vjfQp4608yJ5FxZZH5QGA-QDT ${ }^{20}$ https://youtu.be/TV-TP8lbbik
} 
C. C. Á: Estoy pensando en voz alta, escuchándote; siento que también lo que está pasando es lo que ha hecho ahorita: incrementar la intencionalidad en el para qué generar las imágenes, para qué producir imágenes desde mi celular o desde las herramientas que tengo. Que a veces es la necesidad de una reunión de trabajo, pero a veces también pasa por ejercicios como lo que tú planteas.

Entonces sí, de escucharte siento que también hay un tema de cómo esta situación ha generado una intencionalidad más clara en cómo la gente ya venía produciendo imágenes; pero también esto ha acelerado que, en general, la gente se cualifique un poco más en ser productora de imágenes, porque ya también hay más intencionalidad y es como la opción para mantenerse como ser social.

C. C.: Para cerrar un poco, y en relación a lo que decía Carlos, el semestre pasado me acuerdo que una vez me encontré con una compañera de antropología y me dijo como: «Bueno, iy qué estás haciendo?», y yo como... «No sé (risas), no sé; yo hago videos en el Mambo y estamos en esto y en La partida». De pronto no estoy haciendo un saber experto antropológico, pero no creo que es lo que quiero hacer. Pude darme cuenta ahí que mi ejercicio con La partida es como el tipo de trabajo de ciencia, metodologías cualitativas y reflexión desde la que quiero hacer. No es este de producir saber experto, sino generar espacios para compartir conocimientos y desde ahí generar más cosas; pero no para escribirlo. Igual me encanta escribir, pero para compartirlo, para generar conocimiento en el diálogo y entre ellas y para ellas y ya está. La antropología no es solo este saber experto en documentales súper elaborados; ha sido pensar que hay otras formas también de hacer o lo que permite la antropología o que la antropología permite. Eso también me parece muy significativo pensarlo. En esos ejercicios que se salen de la academia, se salen del saber experto, como desde lo colectivo, desde otros medios; eso me parece bien significativo también.

C. C. Á: Para mí es muy similar a cómo me aproximo: desde qué me permite hacer la antropología y qué le permito a la antropología entrar dentro de lo que yo hago, más allá de pararme en un lugar de antropólogo como un poco se esperaría que es. Creo que es más herramientas que hay ahí, las cuales, mal que bien, a veces consciente, a veces inconsciente, han sido muy útiles para explorar el ejercicio documental, explorar ejercicios también de lo teatral, cuando he estado caminando por ahí. Pasa mucho por temas también de las herramientas que me da la antropología para abrir espacios como tú dices, para tener una mirada y una sensibilidad también para hacer lo que hago, no necesariamente audiovisual. 